\title{
Assessment of Knowledge and Attitude For patients and their Care Givers Regarding to Typhoid Disease in Outpatient Clinics in Fever Hospitals at Assiut Governorate
}

\author{
Asmaa M. Mohamed ${ }^{1}$, Ahmed M. El-Hany ${ }^{2}$, Safaa A. Mohammed \& Asmaa K. Hassan. \\ 1. Nursing Specialist in the Fever Hospital at Dirout City, Assiut, Egypt. \\ 2. Professor of Community Health Medicine, Faculty of Medicine, Assiut University, Egypt \\ 3. Professor of Community Health Nursing, Faculty of Nursing, Assiut University, Egypt. \\ 4. Assistant Professor of Community Health Nursing, Faculty of Nursing, Assiut University, Egypt.
}

\begin{abstract}
Typhoid fever is a systemic bacterial illness of public health importance. The disease is transmitted person to person due to fecal contamination of food and water. Aim: Determine the incidence of typhoid disease for patient and caregiver in hospitals of Assuit governorate. Assess the knowledge, attitude of patient and their caregiver about typhoid fever. Methods: Descriptive cross sectional research design used in the present study. The study was carried out in the fever hospitals of Assuit governorate, which consists from (Assuit fever hospital, Dirout fever hospital, Elshamia fever hospital). Sample was total coverage to all cases attended to the previous setting during six months, the total cases around (400) cases (232) patients and (168) caregiver. Tools of the study was assess the knowledge of patient and caregivers about typhoid fever and their attitude reward typhoid disease. Data collection by direct interview to cases and their caregiver started from first January / 2018 to the end June / 2018, data was analyzed by SPSS version 20.0 Results: It was found that satisfactory knowledge of patient and caregiver related to typhoid disease. It was found that negative attitude of patients and caregivers regarding to typhoid disease. Conclusion and Recommendation: It was conclude that all patients and caregivers knowledge satisfactory while negative attitude were observed that toward typhoid fever. The study recommended that education at programs should be organized for patients and caregivers regarding management and prevention of typhoid fever.
\end{abstract}

\section{Keywords: Assessment, Typhoid Fever, Knowledge, Attitude, Determine, Patients \& Caregivers.}

\section{Introduction}

Typhoid fever (TF) is a life-threatening illness caused by the bacterium Salmonella Typhi. Typhoid fever is not common in the United States, Canada, Western Europe, Australia, or Japan, but it is common in many other countries (CDC, 2018).

The World Health Organization (WHO) estimates that 16-33 million people are infected worldwide each year. Typhoid, or enteric, fever leads to a 200,000 deaths annually; $80 \%$ of these in Asia and the rest primarily in Africa and South America. Recent studies in Asia suggest that the incidence of enteric fever is highest in children aged, 5 years and that Young children experience similar rates of fever (Uttam et al., 2017).

In Bilbeis district (population 664,000) in Lower Egypt the estimated incidence of typhoid fever was calculated to be 13 cases per 100,000 persons per year .Also the results of population-based surveillance in Fayoum governate indicate that incidence of typhoid fever was 59 cases per 100,000 persons per year(Crump et al., 2019).

In Assuit, incidence estimates have been derived from hospital-based syndromic surveillance, which may not represent the population with TF about 1000

\section{patient annually (Assuit Health Affairs} Directorate).

Typhoid fever is an infection that causes clinical symptoms of fever, abdominal pain, body rashes, terry stool, weakness, poor appetite, headaches, generalized aches, pains, lethargy and hapatosplenomegaly will be detectable in about $50 \%$ of patients (N.G.P.H.U., 2017).

It is caused by Salmonellaetyphi, Enter bacteria under Enterobacteriaceae family Gram-negative motile bacteria. Diagnosis of typhoid fever is made when the Salmonella bacteria is detected with blood culture or stool culture. Besides this, several other tests were also performed for early diagnosis of typhoid fever like immunochromatographic assay. Contaminated water or ice, flooding, food and drinks purchased from street vendors, raw fruits and vegetables grown in fields fertilized with sewage, ill household contacts, lack hand washing and toilet access, and evidence of prior Helicobacter Pylori infection, were the most commonly reported risk factors. (Michael et al., 2017).

Complications of typhoid disease include typhoid meningitis, encephalomyelitis, cranial or peripheral 
neuritis, and psychotic symptoms. Other serious complications documented with typhoid fever include hemorrhages (causing rapid death in some patients), Hepatitis, myocarditis, pneumonia, disseminated intravascular coagulation, thrombocytopenia and hemolytic uremic syndrome (Uttam, 2017).

Prevention and control sanitation and hygiene are important to prevent typhoid. Careful food preparation and washing of hands are crucial to prevent typhoid (WHO, 2015).To maintain rural health, water-borne diseases can be reduced by introducing health interventions like proper water and sanitation facilities (Michael et al., 2017).

The role of community health nurse ( $\mathrm{CHN}$ ) to promote health is to improve the self-care of patient and care giver and this may be achieved through health education. CHN educate patient and care giver about health and wellbeing, which can be expected to increase their self-care abilities and promote health such as increase nutritional food choice, physical activity and regular sleep habits (Ali et al., 2017).

\section{Significance of the study}

Typhoid is widely prevalent in all parts of the world but its incidence has considerably declined in developed counters due to improvement in sanitation economic factors and quality of life. In 2015, it resulted in about 149,000 deaths worldwide (Global Burden of Disease, 2016).

David et al. in 2012. The estimated incidence of typhoid fever in Egypt was 15 cases per 100,000 persons per year (Egyptian national syndrome-based surveillance, unpublished data). (Mogasale et al., 2014 ).

In Assuit, incidence estimates have been derived from hospital-based syndromic surveillance, which may not represent the population with typhoid fever about 1000 patient annually (Assuit health affairs directorate).

\section{Subjects \& Methods \\ Research design}

Descriptive cross sectional research design used in the current study.

\section{A- Setting}

The study was carried out in the outpatient clinics at fever hospitals Assuit governorate, which consist of (Assuit fever hospital, Dirout fever hospital, Elshamia fever hospital). Where Assuit fever hospital is high flow in patient intake and highly of patient attendance to provide many services in the villages such as curative service, preventive service, Investigations and outpatient clinics.

\section{B-Sample}

Convenient sample were used. The total number of patients and their caregivers were (400) participant in the current study which they were chosen from all fever hospitals in Assuit governorate of the period of six months As following

Table (1): show the hospitals and the studied sample in each hospital

\begin{tabular}{|l|c|c|}
\hline \multicolumn{1}{|c|}{ District } & $\begin{array}{c}\text { Name of } \\
\text { hospitals }\end{array}$ & $\begin{array}{c}\text { The studied } \\
\text { sample }\end{array}$ \\
\hline Assuit district & $\begin{array}{c}\text { Assuit fever } \\
\text { hospital }\end{array}$ & 200 \\
\hline $\begin{array}{l}\text { Dirout } \\
\text { district }\end{array}$ & $\begin{array}{c}\text { Dirout fever } \\
\text { hospital }\end{array}$ & 100 \\
\hline $\begin{array}{l}\text { Elshamia } \\
\text { district }\end{array}$ & $\begin{array}{c}\text { Elshamia } \\
\text { fever hospital }\end{array}$ & 100 \\
\hline Total & $\mathbf{3}$ & $\mathbf{4 0 0}$ \\
\hline
\end{tabular}

\section{Aim of the study}

1. 1-Determine the incidence of typhoid disease in fever hospitals at Assuit governorate.

2. 2-Assess the knowledge, attitude of patient and their care giver about typhoid fever.

\section{Research questions}

Q1: Are patient and their caregiver have knowledge and attitude about typhoid fever at outpatient clinic in fever hospitals of Assuit governorate?

\section{C-Tools of the study:}

-Interview questionnaire sheet which developed by the researcher after reviewing the relevant literature it included two tools

Tool 1: Included two parts Part 1:Socio demographic characteristics of the patient and their caregivers

- It include sex, age, academic qualification, residence, income, occupation and education

Part 2:Assess the knowledge of patient and their care givers about typhoid fever:- Definition, Causes, Sign and symptoms, Risk factors and treatment of typhoid disease, predisposing factors, typhoid out break response, investigations, family history, complication, prevention and nursing care and total question It was included (16) items for patients and their families .

Tool (2) Assess the attitude of patient and their caregivers about typhoid disease:-Rating scale used to assess attitude of patients and their caregivers about typhoid disease. It was included (18) items for patients and their caregivers. The response were on a three-point likert scale ranging from (I don't know, agree and disagree). Items were scored (0, 1, and 2).

The scoring system of knowledge was as follow: A scoring system

Score of each item summed-up and then converted into a percent score as following: Poor knowledge; Score less than $50 \%$, Fair knowledge; If score is from $50-70 \%$ and Good knowledge ; If score more than $70 \%$ (Abd Elzaher et al., 2014). 
The scoring system of attitude was as follow: A scoring system

Regarding to total scoring for attitude, it consists of (18) questions. Each question is scored using a three point likert score. Patients and caregivers attitude were considered positive attitude if the score was less than $60 \%$ and negative attitude if score is from more than $60 \%$ (Solliman et al., 2013).

\section{Methodology}

I-Administrative phase

An official letter approval obtained from dean of the Faculty of Nursing Assiut University to Assiut governorate, directors of industrial cities and directors of fever hospitals. This letter included a brief explanation of the nature and objectives of the study.

\section{II-Pilot Study}

A pilot study was carried out before starting data collection on $10 \%$ of patients and caregiver from three hospitals (40cases) was excluded from the sample for presence of some modification in the clarity of statement. The pilot study has also served to estimate the time required to fill the form.

Validity of tool: The evaluation of data collection tools was done by five experts from Nursing Faculty and medicine at Assiut University to measure the validity of the tools. It aimed to test the clarity and applicability of the tool to detect any ambiguity in the study tools.

Reliability of tool: was analyzed by Cronbach's alpha the value was 0.791 .

\section{II- Data collection Phase}

\section{Ethical consideration}

Research proposal will be approved from Ethical Committee in the Faculty of Nursing. There is no risk for study subject during application of the research. The study will follow ethical principles in clinical research. Written consent will be obtained from the directors and oral informed consent will be obtained from workers that are willing to participate in the study, after explaining the nature and purpose of the study .Confidentiality and anonymity will be assured. Participants have the right to refuse to participate and or withdraw from the study without any rational any time.

\section{Field work}

Data were collected for the study from first January / 2018 to the end of June / 2018. The investigator introduced himself to initiate a line of communication with health team director of each setting, explain the nature, purpose of the study and obtained consent. The investigator visited the hospitals two days/week. Every day, about eight to nine sheets were finished. The average of time taken for completing each interview questionnaire and dropout about 32 cases was around 15-20 minutes.

\section{Statistical analysis}

Data entry was done by using personal computer by the investigator. The content of each tool was analyzed, categorized, and coded by the investigator. All data were entered into (SPSS) version 20.0 software for analysis and excel for figures. Descriptive statistics (i.e. Percentage, mean \pm standard deviation) were done and for analytical statistics, Chi -squire was used to determine the differences between the knowledge, awareness, attitude, and practice in relation to demographic characteristics of participants. Spearman correlation coefficient was used to determine the correlation between knowledge, attitude because the set of data in the form of frequencies. Statistical significance was considered $\mathrm{p}-$ value $<0.05$. 


\section{Results}

Table (1): Distribution of studied sample (typhoid patients and caregivers) regarding to their sociodemographic characteristics, Assuit Governorate, 2018(N.400).

\begin{tabular}{|c|c|c|c|c|c|}
\hline & \multicolumn{2}{|c|}{$\begin{array}{l}\text { Patients } \\
(n=232) \\
\end{array}$} & \multicolumn{2}{|c|}{$\begin{array}{c}\text { Caregivers } \\
(n=168)\end{array}$} & \multirow[t]{2}{*}{ P-value } \\
\hline & No. & $\%$ & No. & $\%$ & \\
\hline \multicolumn{5}{|l|}{ Hospital: } & \multirow{4}{*}{0.970} \\
\hline Dairout Fever Hospital & 58 & 25.0 & 42 & 25.0 & \\
\hline Assiut Fever Hospital & 115 & 49.6 & 85 & 50.6 & \\
\hline El-Shameia Fever Hospital & 59 & 25.4 & 41 & 24.4 & \\
\hline \multicolumn{5}{|l|}{ Age: (years) } & \multirow{4}{*}{$0.000 *$} \\
\hline$<20$ & 131 & 56.5 & 1 & 0.6 & \\
\hline $20-<40$ & 33 & 14.2 & 113 & 67.3 & \\
\hline$\geq 40$ & 68 & 29.3 & 54 & 32.1 & \\
\hline Mean \pm SD (Range) & \multicolumn{2}{|c|}{$24.98 \pm 19.72$} & \multicolumn{2}{|c|}{$33.55 \pm 8.29$} & $0.000 *$ \\
\hline \multicolumn{5}{|l|}{ Sex: } & \multirow{3}{*}{0.579} \\
\hline Male & 117 & 50.4 & 80 & 47.6 & \\
\hline Female & 115 & 49.6 & 88 & 52.4 & \\
\hline \multicolumn{5}{|l|}{ Educational level: } & \multirow{7}{*}{$0.000 *$} \\
\hline *Under age & 33 & 14.2 & 0 & 0.0 & \\
\hline Illiterate & 16 & 6.9 & 8 & 4.8 & \\
\hline Read \& write & 55 & 23.7 & 35 & 20.8 & \\
\hline Basic education & 67 & 28.9 & 18 & 10.7 & \\
\hline Secondary & 50 & 21.6 & 74 & 44.0 & \\
\hline University & 11 & 4.7 & 33 & 19.6 & \\
\hline \multicolumn{5}{|l|}{ Marital status: } & \multirow{6}{*}{$0.000^{*}$} \\
\hline$* *$ Under age & 116 & 50.0 & 0 & 0.0 & \\
\hline Single & 36 & 15.5 & 18 & 10.7 & \\
\hline Married & 74 & 31.9 & 132 & 78.6 & \\
\hline Divorced & 1 & 0.4 & 8 & 4.8 & \\
\hline Widowed & 5 & 2.2 & 10 & 6.0 & \\
\hline \multicolumn{5}{|l|}{ Occupation: } & \multirow{8}{*}{$0.000 *$} \\
\hline$* * *$ Under age & 116 & 50.0 & 0 & 0.0 & \\
\hline Skilled worker & 11 & 4.7 & 30 & 17.9 & \\
\hline Unskilled worker & 9 & 3.9 & 12 & 7.1 & \\
\hline Employee & 15 & 6.5 & 42 & 25.0 & \\
\hline House wife & 54 & 23.3 & 57 & 33.9 & \\
\hline Farmer & 22 & 9.5 & 8 & 4.8 & \\
\hline Free business & 5 & 2.2 & 19 & 11.3 & \\
\hline \multicolumn{5}{|l|}{ Residence: } & \multirow{3}{*}{0.544} \\
\hline Rural & 130 & 56.0 & 89 & 53.0 & \\
\hline Urban & 102 & 44.0 & 79 & 47.0 & \\
\hline \multicolumn{5}{|l|}{ Income: } & \multirow{4}{*}{0.140} \\
\hline Low & 63 & 27.2 & 32 & 19.0 & \\
\hline Middle & 109 & 47.0 & 83 & 49.4 & \\
\hline High & 60 & 25.9 & 53 & 31.5 & \\
\hline
\end{tabular}

*Under age in educational level is from one year to six years don't reach to stages of educational level.

** Under age in marital status is from one year to 18 years don't reach year of marriage.

*** Under age in occupation is from one year to 16 years don't reach stages of occupation. 
Table (2): Distribution of typhoid patients and their caregivers regarding to their home environmental, Assuit Governorate, 2018 (N 400).

\begin{tabular}{|c|c|c|c|c|c|}
\hline \multirow[t]{2}{*}{ Variables } & \multicolumn{2}{|c|}{$\begin{array}{l}\text { Patients } \\
(n=232)\end{array}$} & \multicolumn{2}{|c|}{$\begin{array}{c}\text { Caregivers } \\
(n=168)\end{array}$} & \multirow[t]{2}{*}{ P-value } \\
\hline & No. & $\%$ & No. & $\%$ & \\
\hline \multicolumn{5}{|l|}{ Ventilation type: } & \multirow{4}{*}{0.059} \\
\hline Natural & 11 & 4.7 & 3 & 1.8 & \\
\hline Industrial & 3 & 1.3 & 7 & 4.2 & \\
\hline Both & 218 & 94.0 & 158 & 94.0 & \\
\hline \multicolumn{5}{|l|}{ If natural: } & \multirow{4}{*}{0.176} \\
\hline Door only & 8 & 3.5 & 1 & 0.6 & \\
\hline Door and window & 76 & 33.2 & 56 & 34.8 & \\
\hline Door and more than one window & 145 & 63.3 & 104 & 64.6 & \\
\hline \multicolumn{5}{|l|}{ In case of window, is there a wire mesh? } & \multirow{3}{*}{$0.020 *$} \\
\hline Yes & 80 & 36.2 & 77 & 48.1 & \\
\hline No & 141 & 63.8 & 83 & 51.9 & \\
\hline \multicolumn{5}{|l|}{ If industrial: } & \multirow{4}{*}{0.129} \\
\hline Fan & 205 & 92.8 & 144 & 87.3 & \\
\hline Both & 6 & 2.7 & 11 & 6.7 & \\
\hline Air conditioning & 10 & 4.5 & 10 & 6.1 & \\
\hline \multicolumn{5}{|l|}{ Water sources: } & \multirow{4}{*}{0.281} \\
\hline Pump & 9 & 3.9 & 7 & 4.2 & \\
\hline Both & 17 & 7.3 & 6 & 3.6 & \\
\hline Tap & 206 & 88.8 & 155 & 92.3 & \\
\hline \multicolumn{5}{|l|}{ Disposal of household waste: } & \multirow{6}{*}{0.790} \\
\hline Pooled and stored in a private place covered & 63 & 27.2 & 42 & 25.0 & \\
\hline Pooled and stored in a private place & 20 & 8.6 & 12 & 7.1 & \\
\hline Pool and burned in front of the house & 26 & 11.2 & 25 & 14.9 & \\
\hline Pool and throw in front of the house & 44 & 19.0 & 29 & 17.3 & \\
\hline Pool and throw away from home & 79 & 34.1 & 60 & 35.7 & \\
\hline Is the house vulnerable to mosquitoes and flies? & & & & & 0.415 \\
\hline Yes & 209 & 90.1 & 147 & 87.5 & \\
\hline No & 23 & 9.9 & 21 & 12.5 & \\
\hline
\end{tabular}

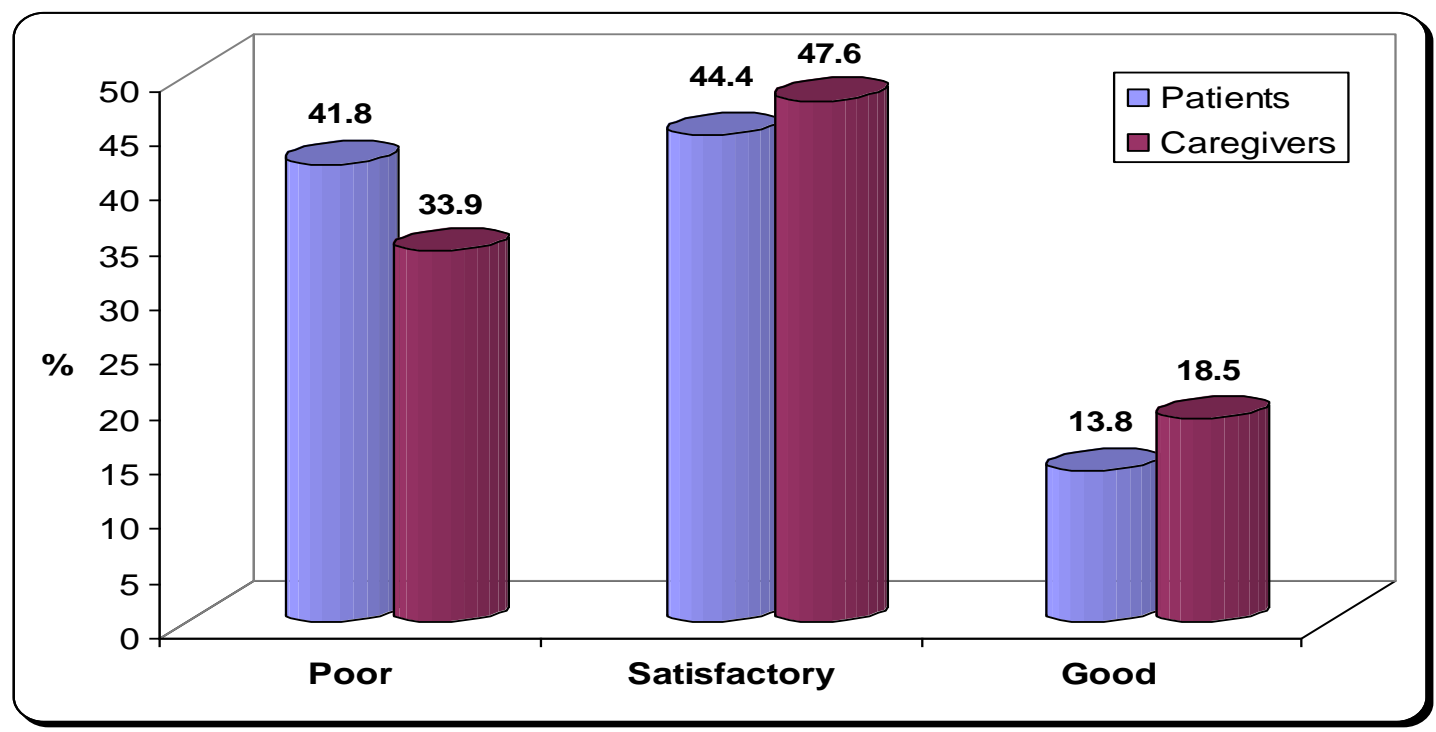

Figure (1): Show: Knowledge of patients and their caregivers related to typhoid disease. 
Table (3): Relationship between sociodemographic characteristics of typhoid fever for patients and their knowledge about the disease, Assuit Governorate, 2018, (N 400).

\begin{tabular}{|c|c|c|c|c|c|c|c|}
\hline \multirow{3}{*}{ Personal characteristics } & \multicolumn{6}{|c|}{ Knowledge level } & \multirow{3}{*}{ P-value } \\
\hline & \multicolumn{2}{|c|}{ Poor } & \multicolumn{2}{|c|}{ Satisfactory } & \multicolumn{2}{|c|}{ Good } & \\
\hline & No. & $\%$ & No. & $\%$ & No. & $\%$ & \\
\hline \multicolumn{7}{|l|}{ Age: (years) } & \multirow{3}{*}{0.749} \\
\hline$<40$ & 40 & 35.1 & 52 & 45.6 & 22 & 19.3 & \\
\hline$\geq 40$ & 17 & 31.5 & 28 & 51.9 & 9 & 16.7 & \\
\hline \multicolumn{7}{|l|}{ Sex: } & \multirow{3}{*}{0.932} \\
\hline Male & 26 & 32.5 & 39 & 48.8 & 15 & 18.8 & \\
\hline Female & 31 & 35.2 & 41 & 46.6 & 16 & 18.2 & \\
\hline \multicolumn{7}{|l|}{ Educational level: } & \multirow{6}{*}{$0.000 *$} \\
\hline Illiterate & 1 & 12.5 & 6 & 75.0 & 1 & 12.5 & \\
\hline Read \& write & 18 & 51.4 & 16 & 45.7 & 1 & 2.9 & \\
\hline Basic education & 10 & 55.6 & 6 & 33.3 & 2 & 11.1 & \\
\hline Secondary & 22 & 29.7 & 39 & 52.7 & 13 & 17.6 & \\
\hline University & 6 & 18.2 & 13 & 39.4 & 14 & 42.4 & \\
\hline \multicolumn{7}{|l|}{ Marital status: } & \multirow{5}{*}{0.375} \\
\hline Single & 6 & 33.3 & 6 & 33.3 & 6 & 33.3 & \\
\hline Married & 47 & 35.6 & 64 & 48.5 & 21 & 15.9 & \\
\hline Divorced & 3 & 37.5 & 4 & 50.0 & 1 & 12.5 & \\
\hline Widowed & 1 & 10.0 & 6 & 60.0 & 3 & 30.0 & \\
\hline \multicolumn{7}{|l|}{ Occupation: } & \multirow{7}{*}{0.340} \\
\hline Unskilled worker & 6 & 50.0 & 4 & 33.3 & 2 & 16.7 & \\
\hline Skilled worker & 9 & 30.0 & 18 & 60.0 & 3 & 10.0 & \\
\hline Employee & 9 & 21.4 & 21 & 50.0 & 12 & 28.6 & \\
\hline Not working & 25 & 43.9 & 23 & 40.4 & 9 & 15.8 & \\
\hline Farmer & 3 & 37.5 & 4 & 50.0 & 1 & 12.5 & \\
\hline Free business & 5 & 26.3 & 10 & 52.6 & 4 & 21.1 & \\
\hline \multicolumn{7}{|l|}{ Residence: } & \multirow{3}{*}{0.125} \\
\hline Rural & 35 & 39.3 & 42 & 47.2 & 12 & 13.5 & \\
\hline Urban & 22 & 27.8 & 38 & 48.1 & 19 & 24.1 & \\
\hline \multicolumn{7}{|l|}{ Income: } & \multirow{4}{*}{0.430} \\
\hline Low & 10 & 31.3 & 15 & 46.9 & 7 & 21.9 & \\
\hline Middle & 28 & 33.7 & 44 & 53.0 & 11 & 13.3 & \\
\hline High & 19 & 35.8 & 21 & 39.6 & 13 & 24.5 & \\
\hline
\end{tabular}

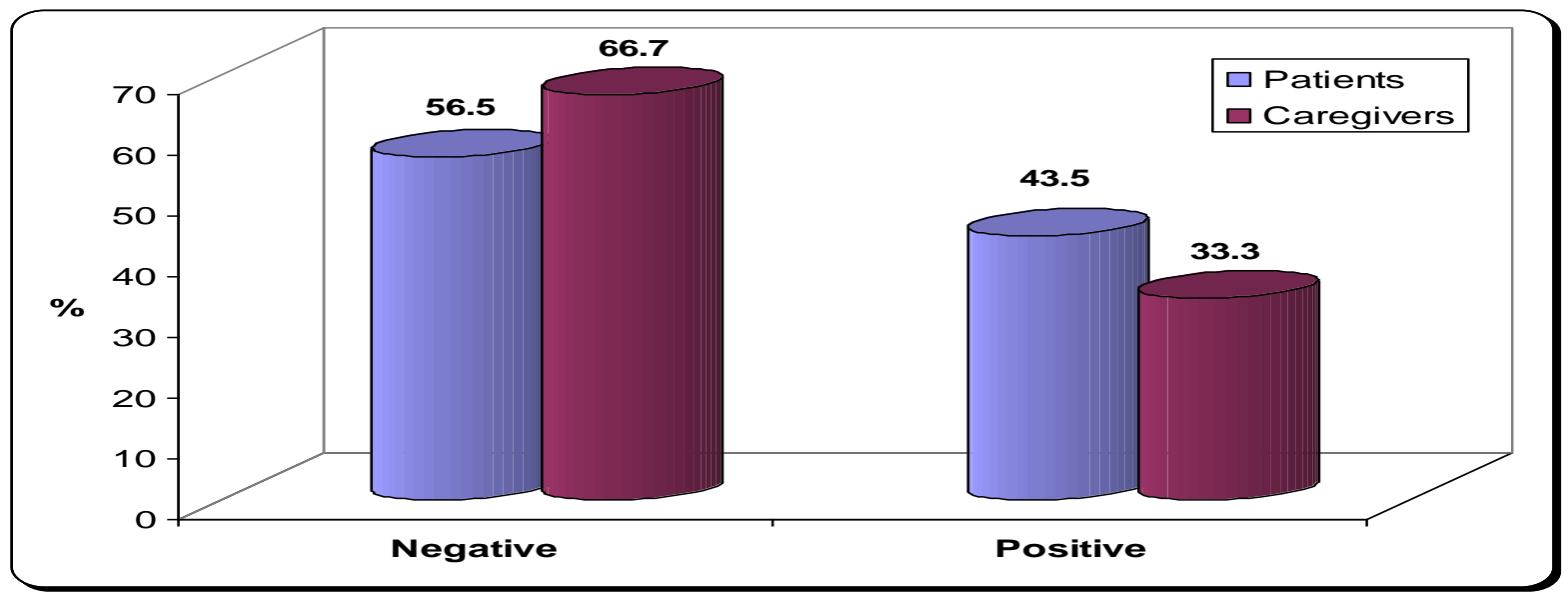

Figure (2) show: Attitude of patients and their caregivers related to typhoid disease. 


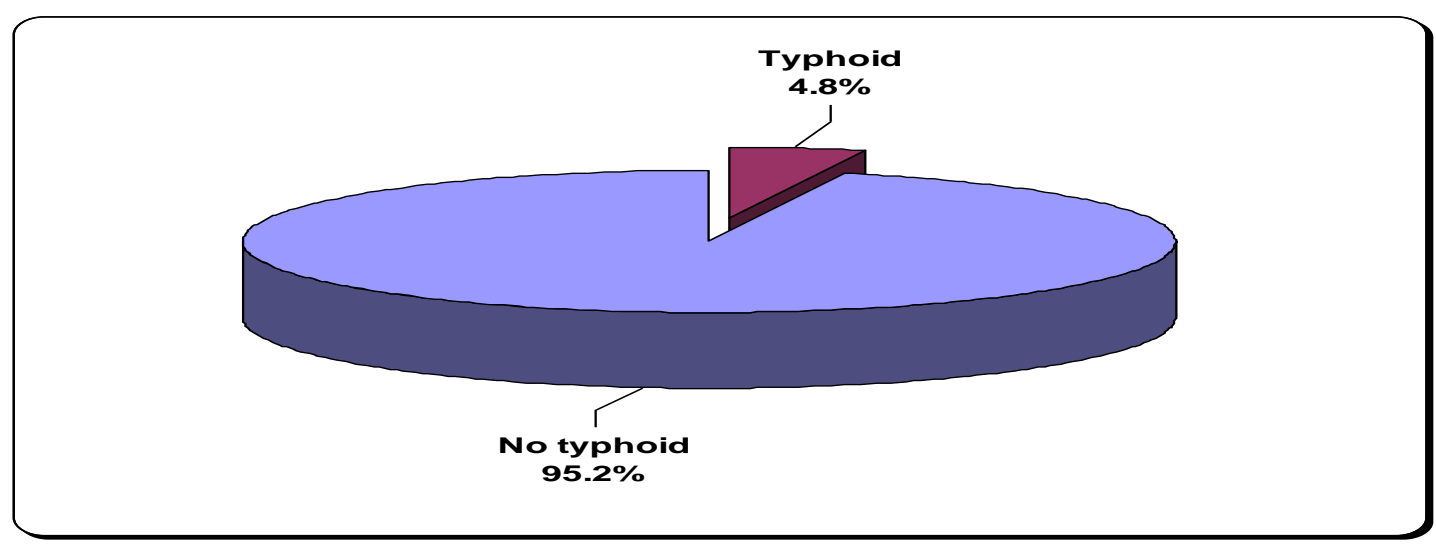

Figure (3) showed that the incidence of typhoid disease in 3 fever hospitals.

Table (4): Relationship between sociodemographic characteristics of typhoid fever for patients and their attitude about the disease, Assuit Governorate, 2018,(N 400).

\begin{tabular}{|c|c|c|c|c|c|}
\hline \multirow{3}{*}{ Personal characteristics } & \multicolumn{4}{|c|}{ Attitude level } & \multirow{3}{*}{ P-value } \\
\hline & \multicolumn{2}{|c|}{ Negative } & \multicolumn{2}{|c|}{ Positive } & \\
\hline & No. & $\%$ & No. & $\%$ & \\
\hline \multicolumn{5}{|l|}{ Age: (years) } & \multirow{3}{*}{$0.014^{*}$} \\
\hline$<40$ & 69 & 60.5 & 45 & 39.5 & \\
\hline$\geq 40$ & 43 & 79.6 & 11 & 20.4 & \\
\hline \multicolumn{5}{|l|}{ Sex: } & \multirow{3}{*}{0.126} \\
\hline Male & 58 & 72.5 & 22 & 27.5 & \\
\hline Female & 54 & 61.4 & 34 & 38.6 & \\
\hline \multicolumn{5}{|l|}{ Educational level: } & \multirow{6}{*}{$0.011 *$} \\
\hline Illiterate & 7 & 87.5 & 1 & 12.5 & \\
\hline Read \& write & 23 & 65.7 & 12 & 34.3 & \\
\hline Basic education & 16 & 88.9 & 2 & 11.1 & \\
\hline Secondary & 40 & 54.1 & 34 & 45.9 & \\
\hline University & 26 & 78.8 & 7 & 21.2 & \\
\hline \multicolumn{5}{|l|}{ Marital status: } & \multirow{5}{*}{0.121} \\
\hline Single & 11 & 61.1 & 7 & 38.9 & \\
\hline Married & 85 & 64.4 & 47 & 35.6 & \\
\hline Divorced & 6 & 75.0 & 2 & 25.0 & \\
\hline Widowed & 10 & 100.0 & 0 & 0.0 & \\
\hline \multicolumn{5}{|l|}{ Occupation: } & \multirow{7}{*}{0.112} \\
\hline Unskilled worker & 10 & 83.3 & 2 & 16.7 & \\
\hline Skilled worker & 20 & 66.7 & 10 & 33.3 & \\
\hline Employee & 32 & 76.2 & 10 & 23.8 & \\
\hline Not working & 30 & 52.6 & 27 & 47.4 & \\
\hline Farmer & 6 & 75.0 & 2 & 25.0 & \\
\hline Free business & 14 & 73.7 & 5 & 26.3 & \\
\hline \multicolumn{5}{|l|}{ Residence: } & \multirow{3}{*}{0.274} \\
\hline Rural & 56 & 62.9 & 33 & 37.1 & \\
\hline Urban & 56 & 70.9 & 23 & 29.1 & \\
\hline \multicolumn{5}{|l|}{ Social class: } & \multirow{4}{*}{$0.001 *$} \\
\hline Low & 29 & 90.6 & 3 & 9.4 & \\
\hline Middle & 45 & 54.2 & 38 & 45.8 & \\
\hline High & 38 & 71.7 & 15 & 28.3 & \\
\hline
\end{tabular}


Table (1): Represent that around half of studied sample (patient and caregivers from Assiut fever hospital .mean age of studied sample were $24.98 \pm$ 19.72 patient and $33.55 \pm 8.29$ Caregivers with statistical differences. Under age represent $(14.2 \%)$ in educational level where under age in educational level is from one year to six years don't reach to stages of educational level. Slight numbers about (21.6) \% of patient have secondary or university school about (4.7) \%. About half of patient under age of married in contrast most of caregivers were married where under age in marital status is from one year to 18 years don't reach year of marriage, with statistical differences. Regarding occupation also about half of studied patient not working and most of caregiver were works where under age in occupation is from one year to 16 years don't reach stages of occupation.. There were no statistical differences between sex, residence or income.

Table (2): Show than there were no statistical significance difference between items of household condition Ventilation type, Water sources, Disposal of household waste )and studied sample( patient and caregivers )

Table (3): Represents the relation between level of patient and caregivers' knowledge about typhoid disease and socio demographic characteristics. It founded that there were statistical significance between some items and level of knowledge as hospital type and educational level.

Table (4): Represents that the relation between level of patients and caregivers attitude about typhoid disease and socio demographic characteristics. It founded that there were statistical significance between some items and level of attitude as hospital type, educational level, marital status, residence and social class.

Figure (1): Show the total sample knowledge of patients and their caregivers related to typhoid disease, which the patient knowledge poor less than half(41.8)\% , satisfactory less than half( (44.4)\% and good $(13.8) \%$ while the caregiver knowledge poor more than third (33.9) ,satisfactory less than half (47.6)\% and good (18.5)\%.

Figure (2): Represents attitude of patients negative more than half (56.5)\% and positive attitude less than half $(43.5) \%$ while caregivers negative attitude more than half $(66.7) \%$ and positive attitude more than third (33.3)\% .

Figure (3) :- showed that the incidence of typhoid was only four and half percentage from total sample where in fever hospitals (Assuit fever hospital, Dirout fever hospital, Elshamia fever hospital) through period six months.

\section{Discussions}

Typhoid fever caused by bacterium called Salmonella enteric a serovar typhi (often referred to as S. typhi). It has become rare developed countries, but remains an important cause of enteric disease in developing countries, resulting in an estimated 216,000 - 600,000 deaths per year, predominantly in children. (Dewan et al., 2013) Typhoid fever and its association with environmental factors in the Dhaka metropolitan area of Bangladesh. The aims of this study were to determine the incidence of typhoid disease in fever hospitals of Assiut governorate and to assess the knowledge, attitude of patient and their care giver about typhoid fever. So, the discussion of the study results presented within the following

There were no statistical differences between sex, regarding the studied sample (patients and care givers) also the results showed that the majority of them were males. This agreement with Bula-Rudas et al., (2015) Salmonella infections in childhood. who found the main sex who suffered from typhoid was male with sixty-five percentage.

The present study found regarding residence the majority of the studied patients and their caregivers were from rural area this agreed with Siddiqui et al., (2015) High prevalence of typhoidal Salmonella enterica serovars excreating food handlers in KarachiPakistan: a probable factor for regional typhoid endemicity, J Health Popul Nutr. who documented that the more than half of typhoid patients were from rural regions that included long distance, difficulty transport, cost, experience and no availability of physicians. In the other hand, Dewan et al., (2013) Typhoid fever and its association with environmental factors in the Dhaka metropolitan area of Bangladesh. Who found that there is no significant difference on the occurrence of typhoid between urban and rural environments ( $\mathrm{p}>0.05)$.

The present study detailed that the majority of the study subjects had tab water in this agreement with Jenkins et al., (2019) Typhoid Fever. The Lancet Infectious Diseases. Who found that there was a statistically significant inverse association which was found between typhoid incidence and distance to major water bodies .In the same aspects Galán, (2016) Typhoid toxin provides a window into typhoid fever and the biology of Salmonella Typhi. Proceedings of the National Academy of Sciences. Mentioned that typhoid risk is higher in populations that; lack access to safe water and adequate sanitation, poor communities and vulnerable groups including children are at highest risk for typhoid infection.

This study explored that more than half of subjects aware about definition and typhoid disease but huge 
numbers of subject know about some items regarding disease information as cause of typhoid disease, methods of infection, This agreed with Tilahun et al., (2017) Modelling and optimal control of typhoid fever disease with cost-effective strategies. Computational and Mathematical Methods in Medicine.This study which emphasized that the bacteria are released from the infectious individuals or carriers and then contaminate food or drinking water as a consequence of unsatisfactory hygiene practices. This due to typhoid fever is a common disease in developing countries.

The majority of the studied patients aware that food consider the main method of typhoid infection, this high score could be explained by the fact that typhoid fever in endemic in Egypt. In this aspect Akabanda et al., (2017) Food safety knowledge, attitudes and practices of institutional food-handlers in Ghana. BMC Public Health. Mentioned that, most of the time typhoid fever is caused by lack of sanitation in which the disease causing bacteria is transmitted by ingestion of contaminated food or water.

The typhoid disease clinically presents with varying clinical features, among such features are fever, abdominal pain, headache, abdominal distension and tenderness especially when the perforation occurred. The current study found patients and care givers were aware that fever, pain, and vomiting as the major features in keeping with previous studies by Phillipo et al., (2012) Typhoid intestinal perforations at a University teaching hospital in North-Western Tanzania: A surgical experience of 104 cases in a resource limited setting. This study not agreed with Casmir et al., (2014) Molecular characterization and antibiotic resistance of Salmonella in children with acute gastroenteritis in Abuja, Nigeria. Journal of Infectious Diseases in Developing Countries .Who found that comparing the prevalence rate of symptomatic and asymptomatic patients of which no statistical significant difference was observed implies that anybody once exposed to typhoid could be infected, while manifestation of symptoms depends on other factors.

Regarding the source of information regarding typhoid disease the present research results showed that most subjects' sources of information are limited to parents and relatives, this because there is no other methods in the community to give accurate knowledge about typhoid disease and its method of infection and prevention. This not agreed with Jabar, \& Sadeq, (2017) Knowledge, attitude and practice of mothers towards typhoid fever disease., Iraqi Journal of Medical Sciences.This study who revealed that; the more typhoid fever cases found in a community the more chance the casual person may acquires knowledge about the disease through contact with medical services such as health centers, hospitals and private clinics.

A study from Nigeria by Afolaranmi et al., (2015) Knowledge and practice of food safety and hygiene among food vendors in primary schools in Jos, Plateau State, North Central Nigeria. Which was about food vendors and its role in typhoid infection) it was showed that fifty four percentage of care givers with good knowledge about typhoid fever among food vendors in primary schools where they gain the medical knowledge. This study is in agreement with a study of Nguri, (2011) Risk factors influencing typhoid fever occurrence among the adults in maina slum, nyahururu municipality, kenya. Master of public health thesis. School of Health Sciences of Kenyatta University. Who revealed that the majority (eighty percentage) had a good knowledge about typhoid receiving this from the medical personnel in the governmental hospitals.

Regarding to the relation between our patient and their caregivers subjects' characteristics and their knowledge bout typhoid disease: This study found that; there is no statistical significant except in educational level. Meanwhile agreed with, Mukaila et al., (2016) Typhoid Perforation: Post-operative Intensive Care Unit Care and outcome. Afr J Paediatr Surg. Who found that; there was a statistical significant relation between patient and care givers education and their total knowledge regarding preventive measures about typhoid diseases $(\mathrm{p}<0.05)$ The present study showed about the most of them greed that Believe that typhoid can be cured and eat well eat will reduces the incidence rate of it. This also agreed with the report of Al Reesi et al., (2016) Severe thrombocytopenia in a child with typhoid fever: a case report. Journal of medical case reports. Who confirm that typhoid most can be treated at home, but you may need to be admitted to hospital if the condition is severe. In addition, around half of them not agree about thinking that the disease affects infants and is not agreed with Kariuki et al., (2015) Antimicrobial resistance and management of invasive Salmonella disease. Who found that distinct seasonality as well as age and gender differences, with males and very young children being disproportionately infected.

Generally, the studied patients and care givers had a negative attitude toward typhoid disease, this agreement with Mauliza, \& Fitriany, (2018) Typhoid Fever Profiles at Cut Meutia Hospital, North Aceh, Indonesia. Recommendation that; decreased health and disease awareness and attitude of residents do indeed reduce the prevalence of typhoid.

The present study showed that; there were statistically difference in all items of their characters. This agreed with Callan et al., (2017) The interrelations between 
social class, personal relative deprivation, and prosociality. Social Psychological and Personality Science. Who found that the personal attitude affected by their age, level of education, and social class.

The present study showed that the incidence of typhoid was only four and half percentage, this not agreed with Malik et al., (2012) Water-borne diseases, cost of illness and willingness to payfor diseases interventions in rural communities of developing countries. Iran J. Public. Health. Who mentioned that The worldwide incidence of Typhoid is approximately 12.5 million cases annually with more than 62 percent of the cases occurring .

\section{Conclusion}

Based on the findings of the present study, it can be concluded that; majority of studied subjects had a satisfactory knowledge level about typhoid disease; and negative attitude were observed regarding toward typhoid fever the majority of them obtained their information regarding typhoid disease from their parents and relatives and from general Hospital.

\section{Recommendations}

- The study finding highlights the need of health updating education Programs as a primary prevention of typhoid disease at Assiut Governorate.

- Utilizing health belief model for assessing children attending $\mathrm{MCH}$ and school students for early detection of typhoid infection.

- Increase community awareness regarding signs and symptoms of communicable diseases to early detection and management through mass media as $\mathrm{TV}$, radio, newspapers, booklet, and other communication channels.

- Encourage the research in area of health education programs regarding of typhoid prevention.

\section{References}

1. Abd Elzaher, O., Qayed, M., Mohamed, S., \& Mohamed, A., (2014): Farmer's knowledge, attitude and practice about pesticides in a village of abnub district. Assiut Governorate. Thesis Master Degree in Community Health Nursing at Faculty of Nursing. Assiut University.

2. Afolaranmi T., Hassan Z., Bello D., (2015): Knowledge and practice of food safety and hygiene among food vendors in primary schools in Jos, Plateau State, North Central Nigeria. J Med Res.; 4(2): 16-22

3. Akabanda, F., Hlortsi, E., \& OwusuKwarteng, J., (2017): Food safety knowledge, attitudes and practices of institutional food- handlers in Ghana. BMC Public Health, 17(1), 40.

4. Al Reesi, M., Stephens, G., \& McMullan, B., (2016): Severe thrombocytopenia in a child with typhoid fever: a case report. Journal of medical case reports, 10(1), 333

5. Ali, M., Yahaya, A., Nas, F., Anas, A., \& Ibrahim, I., (2017): Trends in Treatment and Vaccine Development of Typhoid Fever: A Review. Asian Journal of Biotechnology and Bioresource Technology, 2 (4), P.P.1-7.

6. Bull F., Rathore M., Maraqa N., (2015): Salmonella infections in childhood. Adv Pediatr ; 62:29-58.

7. Callan, M., Kim, H., Gheorghiu, A., \& Matthews, W., (2017): The interrelations between social class, personal relative deprivation, and prosociality. Social Psychological and Personality Science, 8(6), 660-669.

8. Casmir I., Bassey E., Nkiruka F., \& Nazek A., (2014): Molecular characterization and antibiotic resistance of Salmonella in children with acute gastroenteritis in Abuja, Nigeria. Journal of Infectious Diseases in Developing Countries; 8(6):712-719

9. Center For Disease Control and Prevention (CDC) (2018): Typhoid fever information for health professionals archived from the original ;05-25

10. Crump J., \& Kirk M., (2019): Progress in typhoid fever epidemiology. Clin infect Diseases, 68(supplez) 9:45

11. Dewan A., Corner R., Hashizume M., Ongee E., (2103): Typhoid fever and its association with environmental factors in the Dhaka metropolitan area of Bangladesh: a spatial and time-series approach, 7(2), P.P. 1:18

12. http://www. Assuit health affairs directorate (2019)

13. Galán, J., (2016): Typhoid toxin provides a window into typhoid fever and the biology of Salmonella Typhi. Proceedings of the National Academy of Sciences, 113(23), 6338-6344.

14. Global Burden of Disease (GBD) (2015): Mortality and Causes of Death, Collaborators. (8 October 2016). "Global, regional, and national life expectancy, all-cause mortality, and causespecific mortality for 249 causes of death, 2015: a systematic analysis for the Global Burden of Disease Study 2015". Lancet. 388 (10053): 1459-1544.

15. Jabar, R., \& Sadeq, T., (2017): Knowledge, attitude and practice of mothers towards typhoid fever disease., Iraqi Journal of Medical Sciences, 15(1), 71-77 
16. Jenkins, Rene S., Hendriksen, Matthew L., Mikoleit, Karen H., Keddy, R., Leon Ochiai. (2019): Typhoid Fever. The Lancet Infectious Diseases, 385:1136-45.

17. Kariuki S., Gordon M., Feasey N., Parry C., (2015): Antimicrobial resistance and management of invasive Salmonella disease. Vaccine; 33(suppl 3):C21-9

18. Mogasale, V., Maskery, B., Ochiai, R., (2014): Burden of typhoid fever in low-income and middle-income countries: a systematic, literaturebased update with risk-factor adjustment. Lancet Glob Health, 2, 570-580.

19. Malik A., Yasar A., Tabinda A., \& Abubakar M., (2012): Water-borne diseases, cost of illness and willingness to payfor diseases interventions in rural communities of developing countries. Iran J. Public. Health. 41(6), 39-49.

20. Mauliza, K., \& Fitriany, J., (2018): Typhoid Fever Profiles at Cut Meutia Hospital, North Aceh, Indonesia, pp. 395-400).

21. Michael C., Judd., \& Eric D., Mintz (2017): Typhoid \& Paratyphoid Fever. Centers fo Disease Control and Prevention, 1-8.

22. Mukaila O., Arinola A., Oluwaseun K., (2016): Typhoid Perforation: Post-operative Intensive Care Unit Care and outcome. Afr J Paediatr Surg., 8;33:27.

23. National Guidelines for Public Health Units (2017). Typhoid and Paratyphoid Fevers. 1-29. https://ecdc.europa.eu/en/typhoid-andparatyphoid-fever

24. Ngolo, L., Fur, N., \& Olugbenga, O., (2018): Extended Beta-Lactamase (ESBL) Producing Salmonella typhi from Presumptive Typhoid Patients in Nasarawa State, Nigeria.vol6, (3), P. 80:86

25. Nguri K., (2011): Risk factors influencing typhoid fever occurrence among the adults in maina slum, nyahururu municipality, kenya. Master of public health thesis. School of Health Sciences of Kenyatta University; 2011, P.P. 46.

26. Phillipo L., Joseph B., Mheta K., (2012): Typhoid intestinal perforations at a University teaching hospital in North-Western Tanzania: A surgical experience of 104 cases in a resourcelimited setting. World J Emerg Surg; $7: 4$

27. Siddiqui T., Bibi S., Mustufa M., Avaz S., Khan A., (2015): High prevalence of typhoidal Salmonella enterica serovars excreating food handlers in Karachi-Pakistan: a probable factor for regional typhoid endemicity, J Health Popul Nutr; 33, 27

28. Solliman A., Amin O., Hoda M., (2013): Ileal perforation due to tyhoid Fever-Review of operative management and outcome in an urban centre in Nigeria. International Journal of Surgery.11,222

29. Tilahun, G., Makinde, O., \& Malonza, D., (2017): Modelling and optimal control of typhoid fever disease with cost-effective strategies. Computational and Mathematical Methods in Medicine, vol (33) N0. 5., P.P. 1:16

30. Uttam K., (2017): Typhoid Fever-Recent Management, 1-4. Source: http://www.apiindia.org/pdf/medicine_update_2 017/mu_015.pdf

31. World Health Organization (2015): Enhancing the role of community health nursing for universal health coverage. 20,55 